\title{
Montessori Creativity Space: Making a Space for Creativity
}

\author{
Tiziano Fattizzo and Pierfrancesco Vania
}

\begin{abstract}
We describe the creation of the "Montessori creativity space," the maker space of the "Secondo Istituto Comprensivo" primary and middle school of Francavilla Fontana, Italy. The space was inspired by the concept of Malaguzzi's atelier as a learning environment for students, teachers, local associations and artisans. In it, the imagination and action come together to ensure cross-disciplinary learning around robotics, educational electronics, logic, computational thinking, and digital and hand-built artifacts.
\end{abstract}

Keywords Malaguzzi $\cdot$ Maker space $\cdot$ Creative atelier $\cdot$ Fab lab $\cdot$ PNSD $\cdot$ Creativity

\section{Introduction}

Until the late 1960s, the term "atelier" was used in Italy with the meaning of art studio, that is, a place for painting, sculpture, dance and haute couture. Then, the national education system adopted it to mean a setting in which the "aesthetic dimension of learning" can become an educational and training strategy [1].

In early 2016, about 60 years after the initial experiences in the preschools of Reggio Emilia, and more than 30 years after the theorization of Loris Malaguzzi's "Hundred Languages of Children" method [2], the Ministry of Education, University and Research invited primary and lower secondary schools to set up creative ateliers, as part of the National Plan for Digital Education (PNSD).

The objective was to "reinstate the importance of workshop teaching, as a meeting point between knowledge and know-how" and to transform workshops into "places of innovation and creativity." Malaguzzi's Atelier, "a place of research, invention,

\footnotetext{
T. Fattizzo $(\bowtie)$

Secondo Istituto Comprensivo, Francavilla Fontana, Brindisi, Italy

e-mail: tfattizzo@libero.it

P. Vania

Via Enrico Toti, 49, Oria, Brindisi, Italy

(C) The Author(s) 2021

D. Scaradozzi et al. (eds.), Makers at School, Educational Robotics and Innovative

Learning Environments, Lecture Notes in Networks and Systems 240,

https://doi.org/10.1007/978-3-030-77040-2_15
} 
and empathy expressed through 100 languages," becomes "meeting point for manual skills, crafts, creativity and technology" [3].

These are the cultural foundations of the "Montessori Creativity space" of the "Secondo Istituto Comprensivo" primary and middle school of Francavilla Fontana, whose mission is to provide space for the "creative potential" of students, to improve their basic and soft skills. "We all have creative potential," Mark Runco says; "our commitment as parents and teachers is to help children achieve it" [4].

A maker space is a place for students, teachers, local associations and artisans, where action and the imagination come together to encourage cross-disciplinary learning around robotics, educational electronics, logic, computational thinking, and digital and hand-built artifacts [5].

\section{The Context}

The "Secondo Istituto Comprensivo" primary and middle school of Francavilla Fontana has about 1400 students on different sites, including four preschools, one middle school and two elementary schools [6]. The maker space is located in the largest of these, "M. Montessori" elementary school. Opening in 2017 as a place dedicated to non-formal and informal learning, where all students can cultivate the wonder of discovery, as well as their manual skills and creativity.

Within about a year, all the funding needed had come from contributions from the European Regional Development Fund (ERDF) and the Ministry of Education fund for "Creative Ateliers," [7] as well as donations from parents and local businesses, and crowdfunding. We had around $€ 50,000$ to achieve what at the beginning was only a "dream": creating a learning space for educational activities during curricular and non-curricular hours, which would include collaborations between students of different ages, and between teachers. It would be a place where we could work with other educational institutions to offer work experience schemes for secondary school students, and shared "learning by doing" projects in which older students could pass their knowledge, emotions and experiences onto their younger counterparts.

The "Montessori Creativity Space" has become an activity hub for a variety of accredited public and private institutions in and around Francavilla, with the shared intent of collaborating together, including by providing adult education courses. It is a bridging space between the school and the local area.

\section{Work Method}

The "Montessori Creativity Space" is now a reality, and many of the ideas presented above have come to fruition. Covering an area of approximately $180 \mathrm{~m}^{2}$, the maker space can accommodate small groups of students, but also several classes at once, if necessary. It is a place where students can tinker, code, experiment with robotics and 
educational electronics, make prototypes, do 3D printing, and digital and traditional crafts.

It is a multifunctional space that can be arranged into different configurations. An area of about $40 \mathrm{~m}^{2}$ occupied by the school's fab lab, is separated from the rest of the space with movable colored panels, and contains 3D printers and scanners that even work with chocolate and clay, a filament extruder with a plastic shredder for recycling PLA and other plastic waste, a laser cutter and chiller, three cutting plotters, a thermoformer, work tables and various tools (compressor, orbital saw, welding equipment, drills, hammers, screwdrivers, etc.).

An area of about $20 \mathrm{~m}^{2}$, covered in rubber flooring and scattered with colorful cushions, is available for reading, relaxing, debating and metacognition. The remaining $120 \mathrm{~m}^{2}$ feature a large table for robotics and several brightly colored modular tables of different shapes and sizes, arranged into islands, which are meant for team work activities, training, and peer collaboration. Colorful cabinets lining the walls contain various types of robot for younger preschool children [8], and educational electronics kits and various accessories for elementary and middle school students. Finally, graffiti and colorful artwork provide a warm and cheerful atmosphere [9].

A teacher manages the inventory and the schedules of the different spaces and the tools. A voluntary association of teachers, professionals and parents with experience in digital fabrication and networking provides free equipment maintenance, as well as training courses and educational experiments, in which they have involved higher education establishments and craft associations, in order to develop and promote youth entrepreneurship schemes and other innovative projects.

An "innovation department" called Codingkids has been set up in which the digital animator, the innovation team and all the teachers compare good teaching practices.

\section{Relationship Between Space, Technologies, Teaching and Learning Practices}

Studies in recent years have shown that the types of activities conducted at the Montessori Creativity Space help develop lateral thinking, which in turn enhances children's acquisition of skills that are crucial in the 21 st century, such as critical thinking, problem-solving, creativity, curiosity, imagination, communication, and collaboration.

Having a maker on hand has inspired teachers to adapt their teaching methods, and stimulated them to experiment with new ideas, and new ways of thinking and solving problems. The maker plays several roles in our project: he provides technical training to teachers, helps them re-evaluate their teaching methods, and does maintenance on the machines [10]. He also acts as a technical teacher, a direct interface between teacher and students, disrupting their traditional relationship, and favoring an atmosphere of informality that benefits students' creativity and autonomy [11]. The 
maker's role is similar to that of Malaguzzi's atelierista, someone with specific skills, who supports the pedagogical practices of teachers. The maker provides support as the teacher holds the rudder that steers curricular learning, enabling students to express their creativity through multiple idioms.

Regarding student behavior, we have seen that interactions in the mostly group activities are mainly between peers, but also involve teachers and makers. Irrespective of when group activities are set up by the teacher, students express themselves openly and without fear of being judged.

\section{Conclusion}

The maker space was set up with the active participation of all actors in the school's community: head teacher, digital animator, teachers, parents and external technical staff. The equipment purchased meets the teachers' main requirement of revising their teaching practices. All teachers have access to the equipment, and have the assistance of external technical staff who provide courses to help them acquire the skills to use these tools, and practical support during teaching activities.

Finally, the action-research experiences within the maker space in coding, 3D printing, educational robotics and electronics, and tinkering are the basis for sharing good teaching practices [8], even beyond our school community, through seminars in other schools and participation in national training programs for teachers [12].

\section{References}

1. Atelier creativi e laboratori per le competenze chiave-MIUR, http://www.istruzione.it/all egati/2016/Allegato_1.pdf

2. Malaguzzi L.: L'educazione dei cento linguaggi dei bambini. In Zerosei n. 4-5 (1983)

3. Atelier|Reggio Children, http://www.reggiochildren.it/attivita/atelier/

4. Runco, M.A.: Creativity: Theories and Themes: Research, Development, and Practice, Elsevier Science Publishing Co Inc (2006)

5. Feeney, C.: Makerspaces: An Introduction to Innovation Learning Spaces. Think, San Francisco (https://issuu.com/mkthink/docs/makerbook_final_aw)

6. Secondo Istituto Comprensivo "Montessori-Bilotta" di Francavilla Fontana (Brindisi), https:// www.secondocomprensivo.edu.it

7. Atelier creativi—La scuola digitale—MIUR, http://www.istruzione.it/scuola_digitale/prog-ate lier.shtml

8. Guasti, L., Newint-Gori, J.: Maker@ Scuola. Stampanti 3D nella scuola dell'infanzia. Florence, Asso+ Ed. (2017)

9. Guasti, L.: Fare didattica in spazi flessibili: Progettare, organizzare e utilizzare gli ambienti di apprendimento a scuola, Tosi, L., Scuola, G. (eds.), pp. 74-110 (2019)

10. Blackley, S., Sheffield, R., Maynard, N., Koul, R., Walker, R.: Makerspace and reflective practice: advancing pre-service teachers in STEM education. Australian J. Teacher Educ. 42(3), 22-37 (2017) 
11. Blackley, S., Rahmawati, Y., Fitriani, E., Sheffield, R., Koul, R.: Using a 'makerspace' approach to engage Indonesian primary students with STEM. Issues in Educ. Res. 28(1), 18-42 (2018)

12. Guasti, L., Rosa, A.: Maker@Scuola. Florence, Asso+ Ed (2017)

Open Access This chapter is licensed under the terms of the Creative Commons Attribution 4.0 International License (http://creativecommons.org/licenses/by/4.0/), which permits use, sharing, adaptation, distribution and reproduction in any medium or format, as long as you give appropriate credit to the original author(s) and the source, provide a link to the Creative Commons license and indicate if changes were made.

The images or other third party material in this chapter are included in the chapter's Creative Commons license, unless indicated otherwise in a credit line to the material. If material is not included in the chapter's Creative Commons license and your intended use is not permitted by statutory regulation or exceeds the permitted use, you will need to obtain permission directly from the copyright holder. 